\title{
Gabriela Glăvan \\ A Way of No Return: flight to the West in Herta Müller's Novels
}

\begin{abstract}
In this paper I shall explore one of Herta Müller's cardinal tropes, the collective imaginary project of fleeing communist Romania, of massive influence in her novels and biography. Novels such as The Land of Green Plums (1984), The Passport (1986) and Travelling on One Leg (1989) shape a complex perspective on one of the most intense collective desires of Romanians during communism - fleeing the country.
\end{abstract}

Keywords: Romanian Communism; Trauma; Persecution; Minority; Political Refugees.

\section{GABRIELA GLĂvaN}

West University, Timisoara, Romania gabriela.glavan@e-uvt.ro

DOI: $10.24193 /$ cechinox.2020.38.12

\section{Introduction}

Tintend to explore the issue of political flight in two of Müller's most prominent novels, Herztier/The Land of Green Plums (1984) and Der Mensch ist ein großer Fasan auf der Welt /The Passport (1986), while also referring to other writings of similar importance to the discussion, such as The Appointment (1997) or Travelling on One Leg (1989). However, the first two novels, written in the same decade as the events narrated, bear the dramatic mark of an urgency to denounce the catastrophic effects of totalitarianism on individual and collective existence. Both novels rely heavily on autobiographical elements, focusing on the life and memories of a young woman who spent her formative years during the bleak latter part of Ceaușescu's autocratic regime. The Land of Green Plums is a novel of city life, referring to Müller's post-university years, when she worked as a translator in a factory and maintained a close friendship with former colleagues, German ethnics like herself. In a novel that exemplifies "the centrality of loneliness" 1 in a totalitarian regime, the narrator reveals in no uncertain terms the unbearable sense of despair and suffocation that defined collective existence. This massive state of crisis 
articulated a single supreme desire that all citizens had - fleeing for the West, finding a better life abroad, taking any risk in order to escape the fear, hunger and poverty that defined everyday life in Romania in the late 1970s and 1980s. The Passport, set in a rural world that the writer was familiar with, as she was born in the Banat Swabian village of Nitzkydorf, is the rather linear, yet turbulent story of the Windisch family, who decided to leave the country as German ethnics and made excessive efforts to receive passports. No less dire than life in a big city, the apparently uneventful life of the peasants is, on a deeper level, shaken by moral corruption, betrayal and lack of solidarity. As the writer once declared, "the first dictatorship that I knew was the Banat Swabian village," ${ }^{2}$ deploring the alienating conformity that plagued all relationships in the small community. Oppression defined both village and city life, and these novels of the dark Romanian 1980s expose the inner workings of a perpetual struggle for survival, in all its shapes and forms - a struggle to get food, to escape the ever vigilant eye of the Securitate, to keep one's mental and intellectual integrity intact, to avoid lethal risks, such as trying to flee the country by improvising dangerous strategies that often led to certain death. Stained by corruption and prostitution, the mythology of the exemplary community of German ethnics appears, especially in these early novels, as a fraudulent construct, and the social order of the village as fractured and dysfunctional. It has been often argued that Herta Müller's biography and work (often invoked together) prove difficult to connect to a coherent identity, defined in terms of belonging, language and origins. Radu Pavel Gheo concisely stated that Müller's case is a paradigmatic example of "belonging by rejection," in the sense that a problematic identity, impossible to define in clear-cut terms, shapes the writer's trademark as an author and intellectual who defies categories and traditional definitions. Thomas Cooper considered important to notice Müller's "'ambiguous status as an outsider, in several senses." ${ }^{4}$ Although she often focused on issues such as her homeland or the mother tongue,"she was arguably never at home."

\section{Fleeing the Country- Fear and Desire}

$\mathrm{T}$ he writer's fictional identities (usually the narratorial voices of the novels) are often confronted with limits and borders, and this could be considered another trademark of Müller's writing. Her native village and the city where she studied and worked as a young woman are both situated in the Western part of Romania, where the influence and the lure of the West were prevalent. Nevertheless, Müller's complex relationship with the status and principles of borders is fundamentally based on her biographical background as a member of an ethnic minority, the Swabians of Banat. Geographically positioned near the border with Hungary and Serbia (the former Yugoslavia during communism), the region of Banat has been peacefully inhabited by numerous minorities such as Germans (Swabs), the French, Bulgarians, the Roma, Jews, Czechs, to mention just the most numerous groups. The region's often invoked multi-ethnic harmony was not flawless, though. Dramatic fractures of former problematic solidarities, such as the Swabians' collaboration with the Nazi 
regime, were not overlooked in Müller's often merciless exposition of the community's not so morally pristine past. A closer look at this intricate network of concrete and imaginary borders reveals an equally sophisticated structure of relations, refusals and transgressions. The proximity with the West and the unbearable climate of dictatorship catalyzed the vastly shared popular fantasy of fleeing Romania for the West. Once arrived in Hungary or the former Yugoslavia, fugitives could hope other borders would open to them more freely and they could seek political asylum. The political status of the Banat Swabians was further complicated by the fact that although they apparently had easier access to a passport to the West, formalities were difficult and discouraging, and, consequently, a parallel system of bribe and obscure connections flourished.

However, it was notorious that, for the general population, crossing the border during communism was a daunting task, as most illegal attempts at fleeing the country ended in tragedy. In The Land of Green Plums, the writer exposes the grim consequences of many Romanians' desperate tries to escape from Ceaușescu's totalitarian rule: "When the farmers harvested their cornfields, they found withered or bloated corpses, picked over by crows. The farmers took the corn and left the corpses, because it was better not to see them. In autumn, tractors ploughed them under." ${ }^{\prime}$ The tragic melancholy of this unescapable captivity is briefly reflected in a moment in the novel, deserving a closer analysis. A popular song by the Romanian folk-rock band Phoenix, The Canary evokes in dark tones and somber melodic lines the allegory of a small, delicate yellow canary kept in a cage and its futile illusion that it could escape. Launched in the late 1960s, the song became an instant hit with the younger generation witnessing the transformation of their country into a prison, with all authority and power held by Ceaușescu and his political acolytes. In 1977, four members of the band, Josef Kappl, Ovidiu Lipan, Erland Krauser and Nicu Covaci fled the country hidden in Marshall concert speakers, in a truck driven by Covaci and a German friend. The moment is mentioned by Müller in The Land of Green Plums, as the news that the rock musicians managed to escape communism spread rapidly and their act of rebellion became widely known: "Georg lowered his head, making a second chin under the first. He crooned to himself: Yellow canary bird, Yellow as yolk/ With feathers so soft / And eyes so far away. The song was very well known in our country. But two months earlier, the singers had fled the border and the song was banned. Georg washed the song back down his throat with beer."

Although she could have taken advantage of her Swabian origins, Müller often stressed the fact that she refused to take the easy way out and remained unabated in considering herself a political refugee that wanted to leave the country as such. The desire to leave communist Romania was a strong molding element in her own biography and in the lives of many writers and artists of her generation. Her case was unusual in that communist authorities considered her a threat to the internal order and would often harass her that she should leave Romania, as she was deemed a disruptive agent. Moreover, she was part of a group that promoted a specific artistic direction, Aktionsgruppe Banat, reuniting 
other ethnic German young writers, such as William Totok, Richard Wagner and Rolf Bossert. The Securitate carefully monitored their every move, and, in the autumn of 1975, Totok, Wagner, Gerhard Ortinau and the critic Gerhardt Csejka were arrested and accused of planning to flee the country. After this incident, the group was officially banned.

Besides her complex fictional explorations regarding the widespread obsession of fleeing the country, Müller detailed the situation in a volume of conversations with Angelika Klammer, My Homeland Was an Appleseed:

Romania with its endless unfortunate stories of fugitives - they all wanted to flee the country. But there was a magical formula for the German minority: "family reunification". Under this name, the state sold the Germans from Romania for a fixed price per person, gaining consistent income in quotes. In the country, clerks received consistent bribes for passports. An informal industry of emigration emerged, a system of completely hidden or semilegal contact points, where, for a lot of money, one could climb higher on the emigration list. There were no precise rules, for some families the wait could last for fifteen or twenty years. ${ }^{8}$

Müller's long and violent history with the Romanian Securitate was primarily fueled by her refusal to abide to the unwritten rule that, in select cases, it was easier for the regime to eliminate its opponents by approving their petitions to leave the country. The writer insisted to leave on her own terms:
Like all the other friends in my group, I did not want family reunification, as the boxes in the printed forms had nothing to do with our reasons for leaving the country. The forms dealt exclusively with relatives, aunts and uncles from Germany. And, in fine print, it was specified that if questions would not be answered precisely and according to the truth, the application would lose its validity. We all crossed out the questions and each wrote their reasons for emigration: persecutions by the Securitate, the questionings, the home searches, being sacked from factories, layoffs from various schools on grounds of individualism and lack of socialist consciousness, censorship and publication interdictions, and so on and so forth. We then turned over the forms. We took everything into account: that the forms would be declared invalid, or that they would be considered a provocation and they would bring us to trial, or that they wouldn't care and we would still be able to leave, as they would want to get rid of us - as I knew from my own questionings: "Go away into the capitalist swamp, you belong there!"

In their study concerning borders and territoriality in Müller's novels, CornișPope and Hammond argued that "the desire for escape, for passage 'from one state of social being to another', often produces a romanticized vision of the border crossing," ${ }^{10}$ involving tropes that project the dangerous concreteness of the act against a background of permanence and routine. Those who dared to flee would do so by swimming across the Danube, by carefully 
navigating dense corn fields or by hiding in trains that connected Romania to its more Western neighbors. It is rather a banalization of a tremendous act than a romanticization, meant to reflect the collective silent tragedy of those who risked (and lost) their lives trying to flee totalitarianism.

As both Ceaușescus were shrouded in dense mythologies, their biological decline, most visible in the 1980s, fueled various rumors concerning the lamentable health state of the dictator, who appeared decrepit enough in his late sixties in order to be suspected of numerous potentially fatal illnesses. State visits were reimagined as personal medical trips: "He had to go away again, it was whispered: to France or China, Belgium or England, Korea, Libya, Syria, Germany or Cuba. In the whispers, each of his trips was coupled with our desire to flee." ${ }^{11}$ Corniș-Pope and Hammond find it ironical that the larger-than-life cult of the dictator invaded and replaced his official role, turning the international stage into his own private source of wellness. Moreover, the critics note that this dense network of rumors "create an ominous coupling of flight and mortality,"12 one that warns against the perils of trying to escape the tightly secured enclosure of communist Romania. The authors further argue that, in Müller's grim dystopic view, fleeing the country invariably involved either a persistent death wish of those who insisted to proceed with their plans against the undeniable reason that they would most likely fail, or a concrete suicidal mission. Paradoxically, the critics conclude, "flight is more about ending life in Romania than about achieving life abroad." ${ }^{13}$ As Edgar believed, along with many other of his peers, "the secret police itself spreads the rumors about the dictator's illnesses, in order to get people to flee and then catch them." 14

Territorial and border control was one of the strategic pillars of Ceaușescu's dictatorship, aiming to maintain an aseptic distance between the citizens of Communist Romania and fellow states of the Eastern Bloc such as Hungary, the former Yugoslavia or Bulgaria. The Securitate and its omnipresent agents (in Müller's Land..., the sinister Captain Piele/"Skin") often manipulated those it followed and persecuted - the "undesirable elements" - luring them into traps that often led to their death. It is the case of Georg, who desperately went to the passports office and requested to leave the country, implicitly placing himself in the hazardous position of someone who openly opposed the regime. ${ }^{15}$ His attitude in the moment reflects the way many other Romanians felt - unable to recall exactly what he had written in his request form, he did remember that he imperatively expressed his desire to leave the country that very day - "Now I feel better, he said, almost like a human being." ${ }^{16}$ As Corniș-Pope and Hammond noted, escape is semantically connected to "the attainment of humanity," ${ }^{17}$ the fugitive holding real hope to regain their dignity and personal freedom. Georg's fate proved tragic, though - he was found dead beneath a hotel window in Frankfurt, in what appeared to be suicidal circumstances. Although the narrator and Edgar left for Germany as well, Georg's death overshadowed their victory against oppression, signaling the massive scale of abuse and atrocity communism involved. The fictional character's tragic end mirrors the real-life drama of Rolf Bossert, who died in similar circumstances in February 
1986, aged 33, after he apparently jumped from the second floor of the asylum building in Frankfurt, where he and his family were housed. As the Romanian Securitate often followed abroad, terrorized and even killed the enemies of the communist state, Bossert's death was immediately followed by intense speculation that he was the victim of the secret police as well.

Suicide is a major allegory in Müller's novel, as it blurs the limits between individual existence and collective fate. Lola, the narrator's friend, is found dead in her dormitory room, hanged in the closet. The two women seemed bound by an unspoken shared tragedy - as the narrator bluntly expressed it, "Lola was hanging by my belt inside her closet." ${ }^{18}$ As it resulted from her diary notes, Lola had fallen pregnant by one of her many lovers, and unplanned pregnancy was, in Ceaușescu's times, a difficult challenge for women, whose reproductive lives were closely monitored by party appointed gynecologists who performed regular check-ups on them in their workplace. Müller documents this collective drama in a volume of essays, ${ }^{19}$ specifically in a chapter appropriately entitled Hunger and Silk. Here she confirms that she had personally known cases of young women who died as a consequence of the official ban on abortion implemented in 1966 by the infamous Decree 770. Lola, a new member of the Party and the girlfriend of a prominent activist, was either murdered or, shamed and desperate, she killed herself. The belt not only bound the two young women in a dramatic history, but it encompassed an entire spectrum of abuse. As Thomas Cooper noted, ${ }^{20}$ the narrator remembers how, as a child, she was tied by the chair with a belt by her mother in order to have her nails cut, and the abuse she suffered then echoed, over the decades, in the abuse she was subjected to as an adult persecuted by the communist secret police. Lola's mysterious death foreshadows Georg's shocking demise in Frankfurt, under circumstances that could not exclude the interference of the Securitate. The narrator does not hesitate to consider those who tried to flee the country via perilous means downright suicidal - one was relying on dense fog to cross the Danube, "others banked on wind, night, or sunshine. That's the way it is, the same thing means a different thing to each person. Like a favorite color, I said. But I thought: like a way of dying." ${ }^{21}$

\section{Passports to Nowhere}

$\mathrm{M}$ üller's ambivalence towards her Romanian roots is most visible when she reveals the dense moral corruption eroding the social fiber in her birth village. Her auctorial debut relied on this strategy, as Nadirs (Niederungen), published in a censored version in Romania in 1982 and in its original version in Germany in 1984, is an unforgiving perspective upon the massive flaws the define the far from idyllic Swabian village where the writer was born and grew up. As the title unequivocally indicates, The Passport, published in 1986 in Germany, is the bleak story of a family's efforts to obtain passports for the West, and it was written while the author herself was waiting for a resolution in her emigration case. The narrative focuses on Windisch, the village miller whose entire existence revolves around his plan to leave the country. Faced with the common adversities of collectivization and with a permanent state of anxiety in relation to state 
authorities and local figures that traditionally correlate empathy and respect, Windisch discovers the troubling reverse side of his apparently peaceful life. The passport, as a supreme object quantifying victory over the dire adversities of communist life, can be obtained in exchange for bribe and sexual favors. His young daughter, Amalie, has the unfortunate capacity to ease the process by prostituting herself with the priest and the village militia man, and she is willing to pay this price for a chance at a better life in the West. Corruption erodes deeper, though. The original title of the novel Der Mensch is ein grosser Fasan auf der Welt, refers to a proverbial expression that, in both German and Romanian, refer to an ironical use of the word "pheasant", having the meaning of "boaster" and "loser", respectively22. Although the novel primarily focuses on Windisch, his family and his efforts to leave the country, it inevitably reveals the dire circumstances all peasants had to face during communist collectivization. Moreover, Windisch becomes aware of the fact that, in order to get the family's passports, Amalie, their young daughter, had to prostitute herself with the priest and the policeman (back then, the militia man). His response is not one of revolt and protest, as he became aware that his daughter was taking the contraceptive pill and, therefore, she was sexually active and able to intervene in her family's favor. Windisch's conclusion is, cryptically, that "A man is nothing but a pheasant in the world." ${ }^{23}$ This way, rather than acknowledging the severity of the situation and the humiliation his daughter had to subject herself to in order to help her family, he shifted the attention to his own passive attitude toward the young woman's act.
Karin Bauer argues that "while Windisch's contempt for women is tied to a resentment of their self-reliance, he mistakenly assumes the self-confidence women derive from their sexual subjugation to signal a natural proclivity towards prostitution." ${ }^{24}$ On a similar note, Valentina Glajar noted that Müller also depicts (in several of her Romanian novels) a patriarchal society shaped by the ideology of National Socialism. ${ }^{25}$ But not only Windisch's perspective seems inflexible and objectifying, the entire context of his existence appears infected with a pervasive malignant element that heralds death and mortification: "Since Windisch made the decision to emigrate, he sees the end everywhere in the village. And time standing still for those who want to stay." 26 The dark, somber poetic tone of the narrative, strategically projected in short, almost hermetic sentences, stylistically perfects the suggestive dimension of Müller's prose.

The transformative power of the desire to flee the country is most striking in The Appointment. Here, the narrator, a worker in a clothing factory, is routinely questioned by the Securitate, as they suspect she inserts small love notes to foreign men inside the menswear items the factory produces. Marriage to a foreigner was the golden ticket to the free world. Her desperate hyperbolic gesture is no less ridiculous than the official doctrine that denied Romanians basic human rights such as freedom of travel. In Norbert Otto Eke's terms, this is yet another one of Herta Müller's Romanian novels that could be deemed an "allegory of hopelessness." ${ }^{27}$ However, Müller does not leave room for open endings, as she projects these narratives of fear and overpowering desire to flee in the framework of her own 
experience as an immigrant to the West. Published in 1989, Reisende auf einem Bein/ Travelling on One Leg is the story of Irene, a young woman who came to West Berlin from an unnamed country she calls "das andere Land." Although she was of German origins and spoke a remote dialect of the language, she found herself in a hostile, unfamiliar world that proved completely different than what she had imagined. A foreigner in a foreign country, Irene felt more like a prisoner than as an immigrant who managed to flee dictatorship. Echoing the writer's experience with the Securitate, Irene is interviewed by a German clerk that could help integrate her into her new life, yet, as Brigid Haines argued, "the situation transports her mentally back into unwished-for confrontations with authority in 'das andere Land'." ${ }^{28}$ Unable to find her true home, an Aussiedler suspended in between worlds, Müller's protagonist answers the cardinal questions involved in her earlier novels revolving around the collective dream of fleeing communist Romania. Indeed, Travelling on One Leg "is an unsettling mixture of the laconic and the grotesque, of the literal, the surreal- merging empirical experience and dream-and the metaphorical" ${ }^{29}$ and this stylistic unity with the writer's earlier novels accentuates the impression that they articulate a coherent narrative structure in which earlier tensions are later answered, although incompletely and in a rather elusive manner.

\section{Conclusions}

$\mathrm{T}$ The obvious intersection between the fictional and the biographical offers, in the case of Herta Müller's novels narrating her Romanian experience and her immigration to Western Europe, a fertile background for questioning the meaning and impact of the collective fantasy of leaving the country, as it persisted in popular imagination during Ceaușescu's dictatorial regime. Although the writer distances herself gradually from the autofictional code, her Romanian novels, especially Herztier/ The Land of Green Plums (1984) and Der Mensch ist ein großer Fasan auf der Welt / The Passport (1986) reflect the precarity and despair of life behind closed borders. Fleeing meant mortal danger, yet staying and waiting (for passports or for the dictator to die) involved challenges that similarly threatened to annihilate and disintegrate.

\section{Works CiTed}

Bauer, Karin, Gender and the Sexual Politics of Exchange in Herta Müller's Prose, in Brigid Haines, Lyn Marven (eds.), Herta Müller, Oxford University Press, 2013.

Cesereanu, Ruxandra (ed.), Herta Müller: un puzzle. (Studii, eseuri și alte texte)/(Herta Müller:A Puzzle. (Studies, Essays and Other Texts), Cluj-Napoca, S,coala Ardeleană, 2019.

Cooper, Thomas, Herta Müller: Between Myths of Belonging, in John Neubauer, Borbála Zsuzsanna Török (eds.). The Exile and Return of Writers from East-Central Europe. Berlin, De Gruyter, 2009, p. 475-496.

Eke, Otto Norbert, "Macht nichts, macht nichts, sagte ich mir, macht nichts": Herta Müller's Romanian Novels, in Brigid Haines, Lyn Marven (eds.), Herta Müller, Oxford, Oxford University Press, 2013, pp.99-116.

Gheo, Radu Pavel. 2017. Străin în țară străină. Literatura română și graniţa identitară în proza Hertei Müller și a lui Andrei Codrescu.Timișoara: Editura Universității de Vest. 
Glajar, Valentina, The Discourse of Discontent: Politics and Dictatorship in Herta Müller's Herztier (1994), in Valentina Glajar (ed.), The German Legacy in East Central Europe as Recorded in Recent German-Language Literature, New York, Camden House, Rochester, 2004, p. 115-160.

Haines, Brigid, "Die Akute Einsamkeit des Menschen". Herta Müller's Herztier, in Bettina Brandt, Valentina Glajar (eds), Herta Müller. Politics and Aesthetics. Lincoln: University of Nebraska Press, p. 87-108. Haines, Brigid, Littler, Margaret, "Gespräch mit Herta Müller", in Brigid Haines (ed.), Herta Müller, Cardiff, University of Wales Press, 1998, pp.14-24.

Haines, Brigid, «The Unforgettable Forgotten»: The Traces of Trauma in Herta Müller's Reisende auf einem Bein, in German Life and Letters, vol. 55, no. 3, July 2002, pp.266-281.

McGowan, Moray, 'Stadt und Schädel', 'Reisende', and 'Verlorene': City, Self and Survival in Herta Müller's Reisende auf einem Bein, in Brigid Haines, Lyn Marven (eds.), Herta Müller, Oxford, Oxford University Press, 2013, pp.64-83.

Müller, Herta, The Land of Green Plums, Hydra Books, Northwestern University Press, New York, 1998. Müller, Herta, The Passport, London, Serpent's Tale, 1989.

Müller, Herta, The Appointment, Metropolitan Books, New York, 2001.

Müller, Herta, Traveling on One Leg, Northwestern University Press, Evanston, Illinois, 1998.

Müller, Herta, Patria mea era un sâmbure de măr. O discuție cu Angelika Klammer (My Homeland was an Appleseed), Bucharest, Humanitas, 2016.

Müller, Herta, Cristina and Her Double: Selected Essays, Portobello Books Ltd, 2013.

Cornis-Pope, Marcel, Hammond, Andrew, European Fiction on the Borders: The Case of Herta Müller, in Andrew Hammond (ed.), The Novel and Europe. Imagining the Continent in Post-1945 Fiction, Palgrave Macmillan, 2016, pp.143-160.

\section{NoTES}

1. Brigid Haines, "Die Akute Einsamkeit des Menschen". Herta Müller's Herztier, in Bettina Brandt, Valentina Glajar (eds), Herta Müller. Politics and Aesthetics. Lincoln: University of Nebraska Press, p. 89. 2. Brigid Haines, Margaret Littler,"Gespräch mit Herta Müller”, in Brigid Haines (ed.), Herta Müller, Cardiff, University of Wales Press, 1998, pp. 17.

3. Radu Pavel Gheo, Herta Müller-Identitate si respingere, in Ruxandra Cesereanu (ed.), Herta Müller: un puzzle. (Studii, eseuri și alte texte)/(Herta Müller:A Puzzle. (Studies, Essays and Other Texts), Cluj-Napoca, Școala Ardeleană, 2019, p. 11

4. Thomas Cooper, Herta Müller: Between Myths of Belonging, in John Neubauer, Borbála Zsuzsanna Török (eds.), The Exile and Return of Writers from East-Central Europe, Berlin, De Gruyter, 2009, p. 475.

5. Ibidem.

6. Herta Müller, The Land of Green Plums, Hydra Books, Northwestern University Press, New York, 1998, p. 61.

7. Ibidem, p. 60.

8. Herta Müller, Patria mea era un sâmbure de măr. O discuție cu Angelika Klammer (My Country was an Apple Seed. A Conversation with Angelika Klammer), Bucharest, Humanitas, 2016, p. 162, my translation from Romanian.

9. Ibidem.

10. Marcel Cornis-Pope and Andrew Hammond, European Fiction on the Borders: The Case of Herta Müller, in Andrew Hammond (ed.), The Novel and Europe. Imagining the Continent in Post-1945 Fiction, Palgrave Macmillan, 2016, p. 148.

11. Herta Müller, The Land of Green Plums, p. 61.

12. Marcel Cornis-Pope, Andrew Hammond, op. cit., p. 148.

13. Ibidem, p. 149.

14. Herta Müller, The Land of Green Plums, p. 50. 
15. Ibidem, p. 151.

16. Herta Müller, The Land of Green Plums, p. 208.

17. Marcel Cornis-Pope and Andrew Hammond, p. 151.

18. Herta Müller, The Land of Green Plums, p. 22.

19. Herta Müller, Cristina and Her Double: Selected Essays, Portobello Books Ltd, 2013.

20. Thomas Cooper, Herta Müller: Between Myths of Belonging, in John Neubauer, Borbála Zsuzsanna Török (eds.), The Exile and Return of Writers from East-Central Europe. Berlin, De Gruyter, 2009, p. 486. 21. Herta Müller, The Land of Green Plums, p. 162.

22. Thomas Cooper, Herta Müller: Between Myths of Belonging, in John Neubauer, Borbála Zsuzsanna Török (eds.), p. 481.

23. Herta Müller, The Passport, London, Serpent's Tale, 1989, p. 9.

24. Karin Bauer, Gender and the Sexual Politics of Exchange in Herta Müller's Prose, in Brigid Haines, Lyn Marven (eds.), Herta Müller, Oxford University Press, 2013, p. 160.

25. Valentina Glajar, The Discourse of Discontent: Politics and Dictatorship in Herta Müller's Herztier (1994), in Valentina Glajar (ed.), The German Legacy in East Central Europe as Recorded in Recent German-Language Literature, New York, Camden House, Rochester, 2004, p. 125.

26. Herta Müller, The Passport, London, Serpent's Tale, 1989, p. 2.

27. Otto Norbert Eke, "Macht nichts, macht nichts, sagte ich mir, macht nichts": Herta Müller's Romanian Novels, in Brigid Haines, Lyn Marven (eds.), Herta Müller, Oxford, Oxford University Press, 2013, p. 99. 28. Brigid Haines, "The Unforgettable Forgotten": The Traces of Trauma in Herta Müller's Reisende auf einem Bein, in German Life and Letters, vol. 55, no. 3, July 2002, p. 276

29. Moray McGowan,'Stadt und Schädel', 'Reisende', and 'Verlorene': City, Self and Survival in Herta Müller's Reisende auf einem Bein, in Brigid Haines, Lyn Marven (eds.), Herta Müller, Oxford, Oxford University Press, 2013, pp. 64-83. 